\title{
Morphological characterization of insect galls and new records of associated invertebrates in a Cerrado area in Bahia State, Brazil
}

\author{
V. P. Lima ${ }^{a}$ and D. Calado ${ }^{a *}$ \\ ${ }^{a}$ Centro das Ciências Biológicas e da Saúde, Universidade Federal do Oeste da Bahia - UFOB, Rua Professor José Seabra \\ de Lemos, 316, Recanto dos Pássaros, CEP 47808-021, Barreiras, BA, Brazil \\ *e-mail: danielacalado@ufob.edu.br
}

Received: September 19, 2016 - Accepted: July 23, 2017 - Distributed: November 30, 2018

(With 1 figure)

\begin{abstract}
In this study, we report the first records and morphological characterization of galls in a Cerrado area in western Bahia, Brazil. The data were collected monthly over two hours between March and September 2015. Fifteen gall morphotypes were found in twelve plant species distributed among seven families. The plant family with the greatest richness of galls was Fabaceae $(\mathrm{n}=8)$. The following gall morphologies were found: globoid, lenticular, marginal leaf roll, conical, cylindrical, fusiform, spherical and pocket shaped. Cecidomyiidae induced globoid, lenticular, conical, fusiform, spherical and cylindrical morphotypes. In addition, species of microhymenoptera belonging to the Eulophidae, Eurytomidae and Encyrtidae families were found. Marginal leaf roll and pocket-shaped galls induced by Thysanoptera were also verified. Springtails were also identified as a successor. Undescribed species of Schizomyia and Lopesia were recorded in B. cupulata and Andira humilis, respectively.
\end{abstract}

Keywords: biodiversity, plant-insect interaction, herbivory, Cecidomyiidae.

\section{Caracterização morfológica de galhas de insetos e novos registros de invertebrados associados em uma área de Cerrado do Estado da Bahia, Barreiras, Brasil}

\begin{abstract}
Resumo
Nesse trabalho são apresentadas informações sobre a ocorrência e a caracterização morfológica de galhas induzidas por insetos em uma área de Cerrado do Oeste da Bahia, Brasil. Os materiais foram coletados mensalmente durante duas horas entre Março e Setembro de 2015. Foram encontrados quinze morfotipos de galhas em doze espécies vegetais, distribuídas em sete famílias. A família de planta com maior riqueza de galhas foi Fabaceae $(\mathrm{n}=8)$. Com relação à morfologia externa, foram encontradas galhas com forma globoide, lenticular, enrolamento marginal, cônica, cilíndrica, fusiforme, esférica e bolso. Quanto à fauna associada às galhas, os morfotipos globoide, cônico, lenticular, fusiforme, esférico e cilíndrico foram induzidos por Cecidomyiidae. Além disso, espécies de microhimenópteros pertencentes às famílias Eulophidae, Eurytomidae e Encyrtidae foram encontrados. A indução de galhas por Thysanoptera, nos morfotipos enrolamento marginal e formato de bolso, também foi detectada. Espécies de colembôlos foram identificadas como sucessoras. Espécies não descritas de Schizomyia e Lopesia foram registradas em Bauhinia cupulata e Andira humilis, respectivamente.
\end{abstract}

Palavras-chave: biodiversidade, interação inseto-planta, herbivoria, Cecidomyiidae.

\section{Introduction}

Galls are caused by changes in cells, tissues, organs or plants resulting from the action of pathogenic organisms and are formed by hypertrophy, hyperplasia, or both. They represent an interspecific relationship between a plant and another organism and are characterized by the anomalous growth of plant tissues (Fernandes et al., 1988).

It is estimated that the overall number of galling species ranges from 21,000 to 211,000 , with the greatest diversity occurring in warm regions and associated with sclerophyllous vegetation (Lara and Fernandes, 1996). Despite the greater diversity in tropical areas, the taxonomic knowledge of galling species is based mainly on those occurring in temperate areas (Espírito-Santo and Fernandes, 2007). According to Espírito-Santo and Fernandes (2007), the Neotropical Region is the least studied region for Cecidomyiidae and likely for gall-inducing insects in general, considering its high seed plant richness (115,000 species). Fabaceae, Asteraceae, Myrtaceae, Malpighiaceae, Rubiaceae 
and Bignoniaceae are the families with the greatest abundance of galling species (Fernandes and Pessôa, 2011; Gonçalves-Alvim and Fernandes, 2001a; Julião et al., 2002; Urso-Guimarães et al., 2003; Urso-Guimarães and Scareli-Santos, 2006; Mendonça, 2007). Further, Fabaceae stands out by presenting the highest abundance of insect galls (Gonçalves-Alvim and Fernandes, 2001a).

In Brazil, studies involving descriptions of new species, the characterization of developmental stages and associations between host plants and inducers are needed to better understand the species and their distributions. The areas of the Cerrado biome are indicated as having high species richness, but due to its large territory, Coelho et al. (2013) pointed that there are many gaps to be filled in regard to its local biodiversity. For Bahia, information about the occurrence of galling insects is scarce (Nogueira et al., 2016), and recent studies have focused on Caatinga and Caatinga-Cerrado transition areas (Carvalho-Fernandes et al., 2012; Costa et al., 2014).

The Cerrado of western Bahia is shaped by a mosaic of environments and phytophysiognomies, being characterized as an area of extreme importance due to its biodiversity. However, despite its importance, this region has experienced great impacts from anthropic activities, mainly because of the process of unregulated urbanization and agricultural development. According to Araújo (2011), the richness of galling insects is positively related to the richness of plant species. This intimate association with host plants makes galling insects more susceptible to extinction when the vegetation cover is modified or destroyed by anthropic action (Gonçalves-Alvim and Fernandes, 2001b).

Considering that obtaining information about gall occurrence might contribute to the understanding of biodiversity, in this study, we present the morphological characterization of insect galls and new records of associated invertebrates from a Cerrado area in western Bahia, Brazil.

\section{Material and Methods}

The galls were collected at the Reitor Edgard Santos campus of the Universidade Federal do Oeste da Bahia (UFOB) in a dry forest area of the Brazilian Savannah (Cerrado) $\left(11^{\circ} 37^{\prime}\right.$ and $12^{\circ} 25^{\prime} \mathrm{S}$ and $44^{\circ} 34^{\prime}$ and $46^{\circ} 23^{\prime} \mathrm{W}$ ) located in the municipality of Barreiras, Bahia State, Brazil. The Brazilian Savannah climate is characterized by temperatures between $22{ }^{\circ} \mathrm{C}$ and $27^{\circ} \mathrm{C}$ throughout the year and rainfall concentrated between October and March (rainy season), with an annual average precipitation of $1500 \mathrm{~mm}$. The dry season corresponds to the months of April to September (Klink and Machado, 2005). During the period of March to September 2015, samples were collected monthly along a trail next to the Rio de Ondas, Rio Grande basin, affluent of the São Francisco River. The trail was travelled for 2 hours to detect plants containing galls. All plant organs along the trail were examined except the roots. Branches of the plants with galls were photographed, collected and transported to the laboratory in properly labelled plastic bags.
In the laboratory, a portion of the galls was dissected under a stereo microscope to identify the gall inducers. The remaining galls were transferred to plastic containers with wet cotton in order to obtain the adult insects. The samples were examined daily until adult emergence. Botanical material was also collected in order to associate the galling insects with their hosts. Further, it was kept in vials containing $70 \%$ alcohol and between cardboard and newspapers for the subsequent mounting. These samples were taken to the herbarium for identification. Host plants were identified with the help of experts and placed into the Herbarium of the Universidade Federal do Oeste da Bahia.

The galls were characterized morphologically according to their shape, color, trichome presence or absence and plant organ of occurrence (Isaias et al., 2013). The leaf galls were evaluated to determine the position. Natural enemies, such as parasitoids, predators, inquilines and successors, that emerged from the collected material were analyzed. A portion of the obtained inducer insects were preserved in $70 \%$ ethanol and subsequently mounted on permanent slides. A taxonomic key from Gagné (1994) and species descriptions were used to identify the galling species. Hymenopteran parasitoids (adults) were identified to the family level using the key provided by Melo et al. (2012). The samples were deposited in the Entomological Collection of UFOB.

\section{Results}

Fifteen gall morphotypes were found among twelve plant species distributed across seven families (Figure 1, Table 1). The plant family with the highest occurrence of galls was Fabaceae $(\mathrm{n}=8)$. The species Bauhinia brevipes Vogel (Fabaceae) presented the greatest richness of galls $(\mathrm{n}=3)$, followed by Hymenaea courbaril L. (Fabaceae) $(\mathrm{n}=2)$.

The gall shapes were characterized as globoid, lenticular, marginal leaf roll, conical, cylindrical, fusiform, spherical and pocket shaped. In addition, galls presenting green, brown, black and red colors were observed. Most of the galls showed the same color as that of the associated plant organ, and green was the most frequent color among the morphotypes $(66.66 \%)$. We observed that the plant organ with the greatest preference in terms of the inducement of galls was the leaf, where $93.33 \%$ of the galls occurred. There were no verified galls in flowers or fruits. Regarding the position of the leaf galls, these developed on the abaxial surface $(35.71 \%)$, the adaxial surface $(28.57 \%)$ or both $(35.71 \%)$. Additionally, only $26.66 \%$ of the galls presented trichomes.

Relating to the associated fauna (Table 1), the globoid (Figure 3 and 6), conical (Figure 8), spherical (Figure 5), lenticular (Figure 9), fusiform (Figure 14), and cylindrical (Figure 13) morphotypes were induced by Cecidomyiidae. Adult insects emerged from globoid (Figure 1 and 3), spherical (Figure 5), and cylindrical (Figure 13) morphotypes, while only larvae were found in the other morphotypes. Undescribed species of Schizomyia Kieffer, 1889 and Lopesia Rübsaamen, 1908 emerged on Bauhinia cupulata 

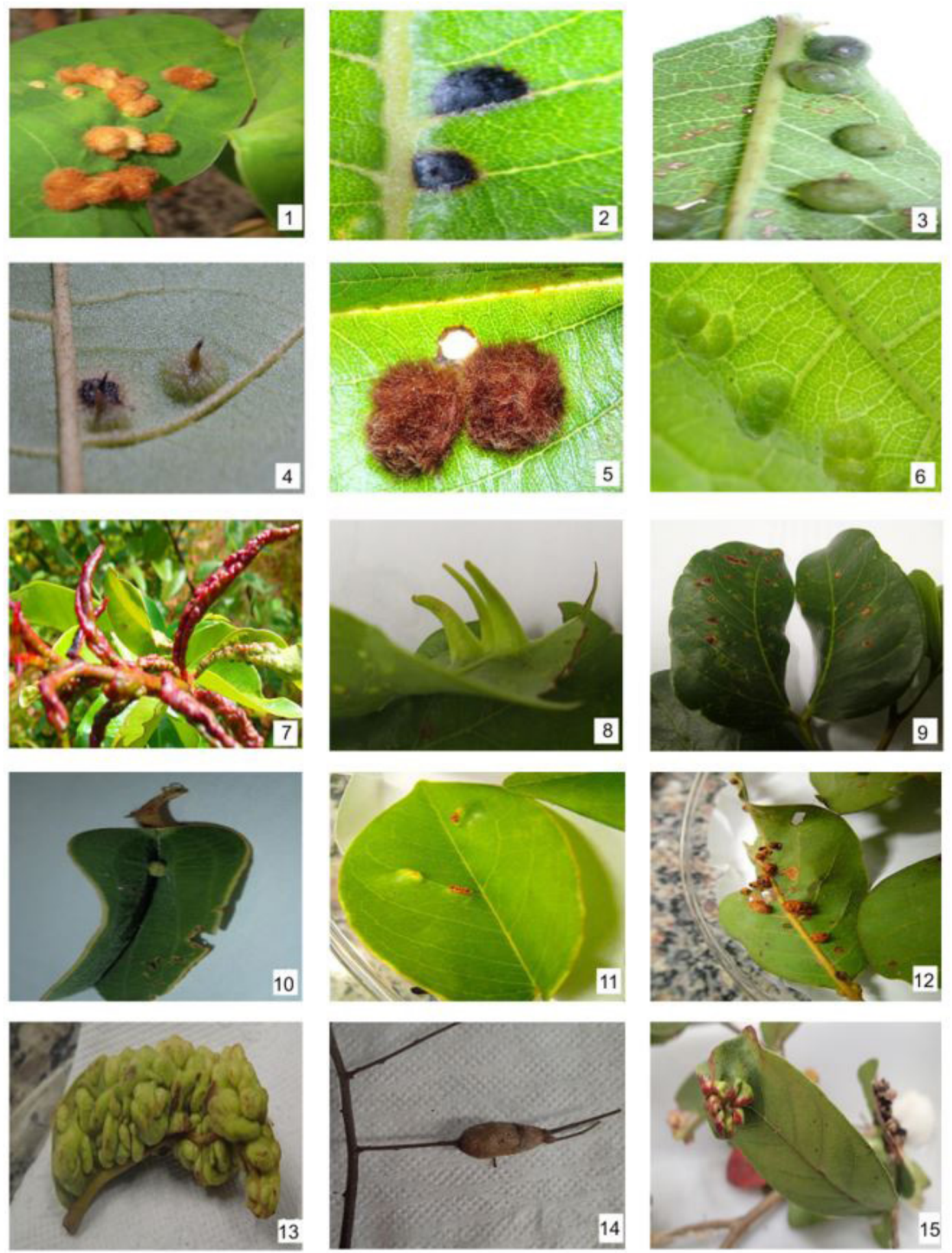

Figures 1-15. Galls found in a Cerrado area from Bahia State (Brazil), from March to September of 2015. 1. Globoid on Bauhinia cupulata; 2. Lenticular on Qualea grandiflora; 3. Globoid on Sapindaceae; 4. Conical on Combretum sp.; 5. Spherical on Bauhinia brevipes; 6. Globoid on Luehea sp.; 7. Marginal leaf roll on Myrtaceae; 8. Conical on Hymenaea courbaril; 9. Lenticular on Hymenaea courbaril; 10. Spherical on Bauhinia brevipes; 11. Cylindrical on Andira cuyabensis; 12. Globoid on Cordia sp.; 13. Cylindrical on Andira sp.; 14. Fusiform on Bauhinia brevipes; 15. Pocket shaped on Myrcia sp. 


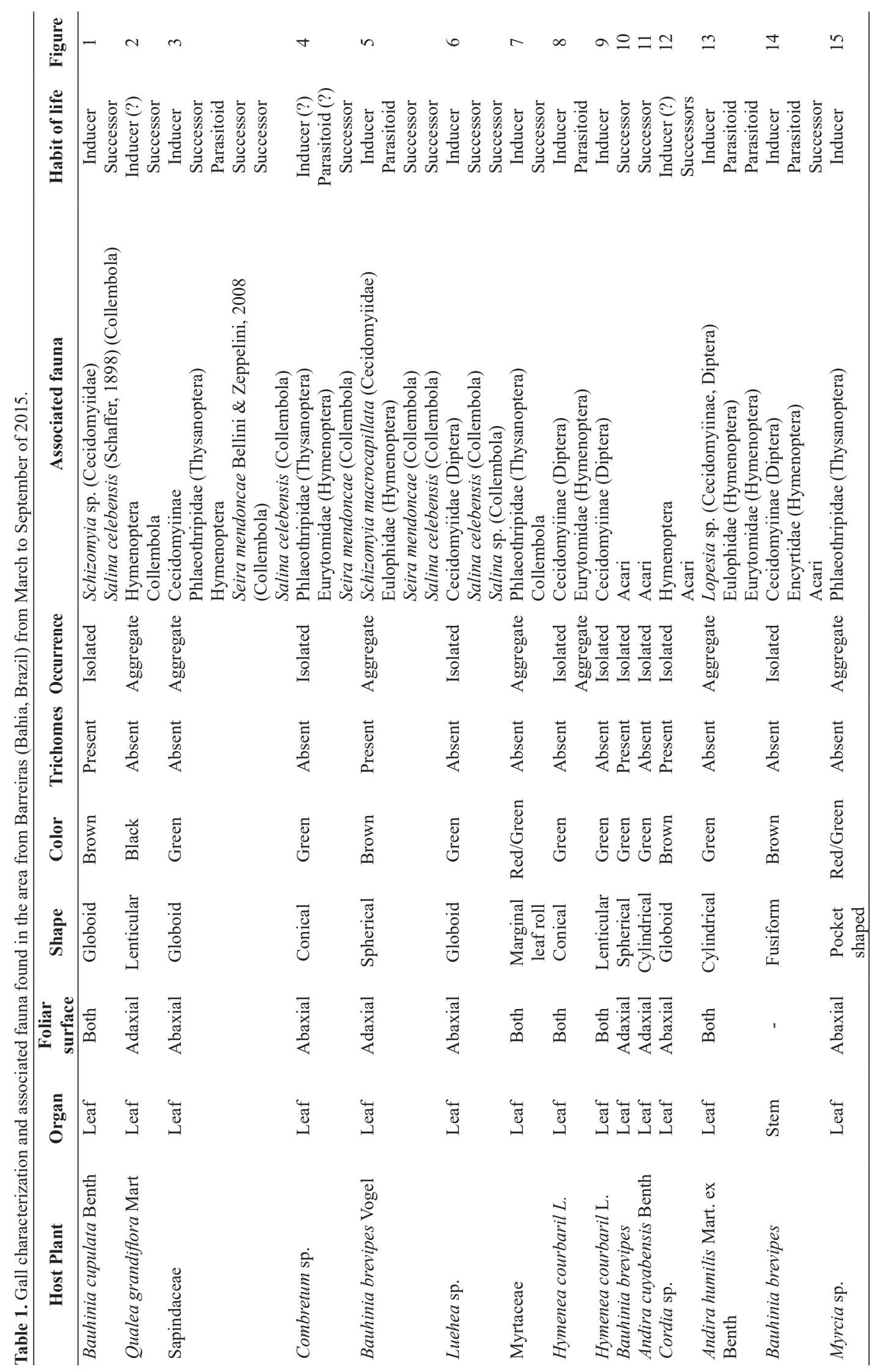


Benth (Fabaceae) and Andira humilis Mart. ex Benth (Fabaceae), respectively. Furthermore, larvae, pupae, and adults belonging to Hymenoptera emerged, which require more information rather than determining their role in the galls. We also observed galls induced by Thysanoptera in the marginal leaf roll (Figure 7) and pocket-shaped (Figure 15) morphotypes. Moreover, mites, thrips and springtails were found in some of the galls that had been abandoned by the inducers (Table 1), which might be classified as successors. Springtails (Collembola) were found in six different galls morphotypes and were thus the main successor, followed by mites (Acari), found in four gall morphotypes.

\section{Discussion}

This study is the first contribution that addresses the occurrence of galls on plant species in western Bahia Cerrado. The results were similar to those of other studies concerning morphology, the location of galls on plants, host-plant preferences and the associated arthropod fauna. In terms of the richness of galls occurring on Fabaceae, Gagné (1994) noted that this plant family is considered to be the main host family for galls in the Neotropical region, with the highest number of associations with cecidomyiids. Moreover, it has been observed that Fabaceae is the most important host family in Cerrado confirming the richness hypothesis (Southwood, 1960; 1961), also recovered by Fernandes et al. (1997), Gonçalves-Alvim and Fernandes (2001b), Santos et al. (2012), Santana and Isaías (2014).

Regarding the morphology of galls, Bregonci et al. (2010) note that most galls have the same coloration as that of the plant organ of occurrence, with a predominance of green colouration as in the leaves. In the present study, it was observed that the coloration of some morphotypes could vary over time. The morphotype called marginal leaf roll collected from Myrtaceae, for example, was originally found with green coloration, possibly in a younger state, but other coloration patterns were observed, such as the color red. In its final state, this morphotype showed a brown coloration, possibly due to gall senescence and the emergence of the gall inducers. According to Abrahamson et al. (1998), gall inducer occurrences offer information that is helpful in resolving some aspects of plant systematics. However, care must be taken when using galls as a character, as these structures can only be used if the morphological changes that occurred during the development of the insects and plant tissues are known and the galling species were identified.

The organ that was most affected by galls was the leaf, a result that was also found in the aboveground portions of plants of the secondary vegetation at Universidade Federal de Minas Gerais, Belo Horizonte, by Fernandes et al. (1988). Santana and Isaías (2014) observed in Park Serra Verde in Belo Horizonte, MG, the occurrence of galls in four different plant organs (leaves, stems, buds and inflorescences), verifying the highest proportion of leaf galls, which was approximately $71 \%$ of the total.
As for the inducing agent, Cecidomyiidae (Diptera) was found in five morphotypes: globoid, lenticular, conical, fusiform, and cylindrical. Cecidomyiidae is the main galling family in all zoogeographic regions (Fernandes et al., 1988; Luz et al., 2012; Maia, 2011; Santana and Isaías, 2014). Here, we also noticed that the majority of gall inducers belonged to Cecidomyiidae.

In this study, we found one undescribed species of Schizomyia (Diptera, Cecidomyiidae) on B. cupulata (Fabaceae). Other species of Schizomyia also occur in Bauhinia genus, Schizomyia tuiuiu Urso-Guimarães and Amorim (2002) was described on Bauhinia rufa (Bong.) Steud. (Fabaceae) from Cuiabá (Mato Grosso), and Schizomyia macrocapillata (Maia and Fernandes, 2005) on Bauhinia brevipes Vogel (Fabaceae) from Três Marias (Minas Gerais). The new species in our study can be distinguished from other species of Schizomyia associated with Bauhinia in having palpi with an obconical first segment (it is spherical in S. macrocapillata and cylindrical in $S$. tuiuiu), labellae with an acuminate apex (rounded edge in other species), and gonocoxites that are longer than those in $S$. macrocapillata (the male of $S$. tuiuiu is unknown). This new species is currently under description.

The plant species H. courbaril (Fabaceae) presented two gall types (conical and lenticular). Copinolasioptera salvadorensis Mohn, 1975 was described on H. courbaril (Fabaceae) in La Libertad, El Salvador (Gagné and Jaschhof, 2014). However, we did not find any information in literature regarding to gall morphotype in order to relate it to our study.

Some species of the genus Combretum Loefl. (Combretaceae) was described as hosting galls in the literature, such as those induced by Houardodiplosis rochae Tavares, 1925 on Combretum leprosum Mart. and Eicher (Combretaceae) in Fortaleza, Ceará (Brazil); Lopesiella combreti Tavares, 1908 on Combretum galpinii Engl. and Diels (Combretaceae) in Mozambique and Neolasioptera combreti Mohn, 1964, on Combretum farinosum Kunth (Combretaceae) in El Cimarron, El Salvador (Gagné and Jaschhof, 2014). Although some species of Cecidomyiidae was described on Combretum, only Phlaeothripidae (Thyssanoptera), Eurytomidae (Hymenoptera) and Seira mendoncae Bellini and Zeppelini, 2008 emerged in our investigation.

In Andira Lam. (Fabaceae), two species of Cecidomyiidae was described in the literature. Andirodiplosis bahiensis Tavares, 1920 was collected in the city of Salvador, Bahia, Brazil, on Andira sp., and Asphondylia andirae Mohn, 1959 was obtained in El Salvador, La Libertad, San Diego, on Andira inermis Wright (Fabaceae) (Gagné and Jaschhof, 2014). In this study, the genus Lopesia (Diptera, Cecidomyiidae) was first observed in A. humilis, demonstrating that this is a new species of Cecidomyiidae that needs to be described because the galls are species-specific, and there is no record of this species in the literature.

Cordia L. (Boraginaceae) hosts species of Cecidomyiidae described from El Salvador, Asphondylia cordiae Mohn, 1959 described on Cordia dentate Poir. (Fabaceae); 
Meunieriella cordiae Mohn, 1959 on Cordia alliodora (Ruiz and Pav.) (Fabaceae) and Neolasioptera cordiae Mohn, 1964 on Cordia cana M. Martens and Galeotti (Fabaceae). In Brazil, there is one species of Cecidomyiidae in a Restinga area in Barra of Maricá (Rio de Janeiro), Cordiamyia globosa Maia, 1996 associated to the galls on Cordia verbenacea D.C. (Fabaceae) (Gagné and Jaschhof, 2014). However, we found only Hymenoptera and Acari associated to the galls in Cordia.

Santana and Isaías (2014) found pocked-shaped galls on Myrcia splendens (Sw.) D.C. (Myrtaceae) induced by Thysanoptera and on Myrcia tomentosa (Aubl.) D.C. (Myrtaceae) in which the inducer was not identified. In our study, we found the same morphotype on Myrcia sp., and we noticed that thrips belonging to Phlaeothripidae family were the inducers. According to Lindner et al. (2016), most of the galling thrips belong to the Phlaeothripidae, and only a few species of Thripidae have a galling habit.

Maia et al. (2008) showed in a study of gall occurrence in Restinga (coastal shrubs) in Bertioga, São Paulo, that Thysanoptera induced marginal leaf roll galls, and we also observed this in our study (Figure 7). Moreover, Santana and Isaías (2014) observed in Park Serra Verde, a conservation area located in the city of Belo Horizonte, that pocket-shaped galls (Figure 15) are also induced by Thysanoptera. Regarding the other insects observed in the galls, further investigations should be carried out to identify the associated species and their living habits.

In relation to the other invertebrates collected, Price (2005) reported that many organisms may be associated with galls. These organisms include predators, parasitoids, inquilines and successors. These can be represented by many taxa, such as Collembola, Acari, Hymenoptera, Coleoptera, Lepidoptera, Thysanoptera, Diptera, Hemiptera, and Psocoptera (Bregonci et al., 2010). In this study, two species of Collembola, Seira mendoncae Bellini and Zeppelini, 2008 (Entomobryidae) and Salina celebensis Schaffer, 1898 (Entomobryidae) were recorded for the first time in Bahia state. Only four springtails had been recorded in this Brazilian state until now: Isotomurus palustris Costa, 1961 (Isotomidae), Temeritas caatingae Arlé and Oliveira, 1977 (Sminthuridae), Brachystomella agrosa Mendonça and Arlé, 1992 (Brachystomellidae), and Dicranocentrus heloisae Arlé and Mendonça, 1982 (Entomobryidae) (Culik and Zeppelini-Filho, 2003; Abrantes et al., 2010).

Hymenoptera is a large and diverse taxon, which includes the main natural enemies of galling insects. Microhymenoptera species are frequently found on galls induced by Cecidomyiidae, acting most often as parasitoids, and in some cases as phytophagous, capable of even modifying the structure and morphology of galls (Maia and Azevedo, 2009; Carvalho-Fernandes et al., 2016). For Restinga areas, Rio de Janeiro (Brazil), Maia and Azevedo (2009) verified that the great majority of micro-hymenoptera was parasitoid, but some of them, for example Tanaostigmatidae and few species of Torymidae and Eulophidae were inquilines of galls. In our study, some parasitoids were identified, but we consider that more investigation is required in order to understand better the status of micro-hymenoptera collected.

According to Maia (2001), galls represent a true microhabitat where several trophic relationships are established. For this reason, cecidomyiids have been called "ecosystem engineers", demonstrating the ecological importance of this group (Espírito-Santo and Fernandes, 2007). Galling insects have a unique biology and are characterized by very specific interactions with host plants (Gonçalves-Alvim and Fernandes, 2001a). Hence, the importance of understanding the biology of this group, as well as their ecological interactions. Our results indicate that the diversity of gall associated insects in Cerrado is poorly known and that many new species of Cecidomyiidae remain to be described.

\section{Acknowledgements}

We thank CNPq for the scholarship and the herbarium of the Universidade Federal do Oeste da Bahia on behalf of Professor Dr. Juliana Gastaldello Rando for the identification of host plants. We thank Maria Aparecida de Alencar Ribeiro for assistance in assembling the slides and the identification of springtails, Amilton Pereira dos Santos for helping in the collections throughout the study and an anonymous referee for very useful criticisms.

\section{References}

ABRAHAMSON, G.A., MELIKA, G., SCRAFFORD, R. and CSOKA, G., 1998. Gall-inducing insects provide insights into plant systematic relationships. American Journal of Botany, vol. 85 , no. 8 , pp. 1159-1165. PMid:21685000. http://dx.doi. org/10.2307/2446348.

ABRANTES, E.A., BELLINI, B.C., BERNARDO, A.N., FERNANDES, L.H., MENDONÇA, M.C., OLIVEIRA, E.P., QUEIROZ, G.C., SAUTTER, K.D., SILVEIRA, T.C., QUEIROZ, G.C and ZEPPELINI, D., 2010. Synthesis of Brazilian Collembola: an update to the species list. Zootaxa, vol. 2388, pp. 1-22.

ARAÚJO, W.S., 2011. Size, age and composition: characteristics of plant taxa as diversity predictors of gall-midges (Diptera: Cecidomyiidae). Revista de Biología Tropical, vol. 59, no. 4, pp. 1599-1607. PMid:22208077.

BREGONCI, J.M., POLYCARPO, P.V. and MAIA, V.C., 2010. Galhas de insetos do Parque Estadual Paulo César Vinha (Guarapari, ES, Brasil). Biota Neotropica, vol. 10, no. 1, pp. 265-274. http:// dx.doi.org/10.1590/S1676-06032010000100023.

CARVALHO-FERNANDES, S.P., ALMEIDA-CORTEZ, J.S. and FERREIRA, A.L.N., 2012. Riqueza de galhas entomógenas em áreas antropizadas e preservadas de Caatinga. Revista Árvore, vol. 2, no. 2, pp. 269-277. http://dx.doi.org/10.1590/S010067622012000200008 .

CARVALHO-FERNANDES, S.P., ASCENDINO, S., MAIA, V.C. and COURI, M.S., 2016. Diversity of insect galls associated with coastal shrub vegetation in Rio de Janeiro, Brazil. Anais da Academia Brasileira de Ciencias, vol. 88, no. 3, pp. 1407-1418. PMid:27627066. http://dx.doi.org/10.1590/0001-3765201620150658. 
COELHO, M.S., CARNEIRO, M.A.A., BRANCO, C.A. and FERNANDES, G.W., 2013. Gall-inducing insects from Serra do Cabral, Minas Gerais, Brazil. Biota Neotropica, vol. 13, no. 3, pp. 102-109. http://dx.doi.org/10.1590/S1676-06032013000300013.

COSTA, E.C., CARVALHO-FERNANDES, S.P. and SANTOSSILVA, J., 2014. Galhas entomógenas associadas à Leguminosae do entorno do riacho Jatobá, Caetité, Bahia, Brasil. Brazilian Journal of Biosciences, vol. 12, pp. 115-120.

CULIK, M.P. and ZEPPELINI-FILHO, D., 2003. Diversity and distribution of Collembola (Arthropoda: Hexapoda) of Brazil. Biodiversity and Conservation, vol. 12, no. 6, pp. 1119-1143. http://dx.doi.org/10.1023/A:1023069912619.

ESPÍRITO-SANTO, M.M. and FERNANDES, G.W., 2007. How many species of galling insects are there on earth and where they are? Annals of the Entomological Society of America, vol. 100, pp. 95-99.

FERNANDES, G.W., ARAÚJO, R.C., ARAÚJO, S.C., LOMBARDI, J.A., PAULA, A.S., LOYOLA JÚNIOR, R. and CORNELISSEN, T.G., 1997. Insect galls from savanna and rocky fields of the Jequitinhonha valley, Minas Gerais, Brazil. Naturalia, vol. 22, pp. 221-244.

FERNANDES, G.W.A., TAMEIRÃO NETO, E. and MARTINS, R.P., 1988. Ocorrência e caracterização de galhas entomógenas na vegetação do Campus Pampulha da Universidade Federal de Minas Gerais. Revista Brasileira de Zoologia, vol. 5, no. 1, pp. 11-29. http://dx.doi.org/10.1590/S0101-81751988000100002.

FERNANDES, P.A. and PESSÔA, V.L.S., 2011. O cerrado e suas atividades impactantes: uma leitura sobre o garimpo, a mineração e a agricultura mecanizada. Revista Eletrônica de Geografia, vol. 3, pp. 19-37.

GAGNÉ, R.J. 1994. The gall midges of the Neotropical Region. Ithaca: Cornell University Press. 364 p.

GAGNÉ, R.J. and JASCHHOF, M., 2014 [viewed 10 April 2016]. A Catalog of the Cecidomyiidae (Diptera) of the World [online]. 3rd ed. Available from: http://www.ars.usda.gov/SP2UserFiles/ Place/12454900/Gagne_2014_World_Cecidomyiidae_Catalog_3rd Edition.pdf.

GONÇALVES-ALVIM, S.J. and FERNANDES, G.W., 2001a. Biodiversity of galling insects: historical, community and habitat effects in four Neotropical savannas. Biodiversity and Conservation, vol. 10, no. 1, pp. 79-98. http://dx.doi.org/10.1023/A:1016602213305.

GONÇALVES-ALVIM, S.J. and FERNANDES, G.W., $2001 \mathrm{~b}$. Comunidades de insetos galhadores (Insecta) em diferentes fitofisionomias do Cerrado em Minas Gerais. Revista Brasileira de Zoologia, vol. 18, no. 1, suppl. 1, pp. 289-305. http://dx.doi. org/10.1590/S0101-81752001000500025.

ISAIAS, R.M.S., CARNEIRO, R.G.S., OLIVEIRA, D. and SANTOS, J.C., 2013. Illustrated and annotated checklist of brazilian gall morphotypes. Neotropical Entomology, vol. 42, no. 3, pp. 230-239. PMid:23949804. http://dx.doi.org/10.1007/ s13744-013-0115-7.

JULIÃO, G.R., AMARAL, M.E.C. and FERNANDES, G.W., 2002. Galhas de insetos e suas plantas hospedeiras no Pantanal sul-mato-grossense. Naturalia, vol. 27, pp. 47-74.

KLINK, C.A. and MACHADO, R.B., 2005. A conservação do Cerrado brasileiro. Megadiversidade, vol. 1, no. 1, pp. 149-154.
LARA, A.C.F. and FERNANDES, G.W., 1996. The highest diversity of galling insects: Serra do Cipó, Brazil. Biodiversity Letters, vol. 3, no. 3, pp. 111-114. http://dx.doi.org/10.2307/2999724.

LINDNER, M.F., MENDONÇA, M.S. and CAVALLERI, A., 2016. Holopothrips molzi sp.n. (Thysanoptera, Phlaeothripidae): natural history and interactions in Myrtaceae galls. Zootaxa, vol. 4114, no. 2, pp. 139-148. PMid:27395120. http://dx.doi. org/10.11646/zootaxa.4114.2.3

LUZ, G.R., FERNANDES, G.W., SILVA, J.O., NEVES, F.S. and FAGUNDES, M., 2012. Insect galls in xeric and mesic habitats in a Cerrado-Caatinga transition in northern Minas Gerais, Brazil. Neotropical Biology and Conservation, vol. 7, no. 3, pp. 171-187. http://dx.doi.org/10.4013/nbc.2012.73.04.

MAIA, V.C. and AZEVEDO, M.A.P., 2009. Micro-himenópteros associados com galhas de Cecidomyiidae (Diptera) em Restingas do Estado do Rio de Janeiro (Brasil). Biota Neotropica, vol. 9, no. 2, pp. 151-164. http://dx.doi.org/10.1590/S1676-06032009000200015.

MAIA, V.C. and FERNANDES, G.W., 2005. Two new species of Asphondyliini (Diptera: Cecidomyiidae) associated with Bauhinia brevipes (Fabaceae) in Brazil. Zootaxa, vol. 1091, no. 1, pp. $27-$ 40. http://dx.doi.org/10.11646/zootaxa.1091.1.2.

MAIA, V.C., 2001. The gall midges (Diptera, Cecidomyiidae) from three restingas of Rio de Janeiro State, Brazil. Revista Brasileira de Zoologia, vol. 18, no. 2, pp. 583-629. http://dx.doi. org/10.1590/S0101-81752001000200028.

MAIA, V.C., 2011. Characterization of insect galls, gall makers, and associated fauna of Platô Bacaba (Porto de Trombetas, Pará, Brazil). Biota Neotropica, vol. 11, no. 4, pp. 38-53. http://dx.doi. org/10.1590/S1676-06032011000400003.

MAIA, V.C., MAGENTA, M.A.G. and MARTINS, S.E., 2008. Ocorrência e caracterização de galhas de insetos em áreas de restinga de Bertioga (São Paulo, Brasil). Biota Neotropica, vol. 8, no. 1, pp. 357-368. http://dx.doi.org/10.1590/S1676-06032008000100020.

MELO, G.A.R., AGUIAR, A.P. and GARCETE-BARRET, B.R., 2012. Hymenoptera. In: J.A. RAFAEL, ed. Insetos do Brasil. Ribeirão Preto: Holos Editora, pp. 553-628.

MENDONÇA, M.S., 2007. Plant diversity and galling arthropod diversity searching for taxonomic patterns in an animal-plant interaction in the Neotropics. Boletin de la Sociedad Argentina de Botánica, vol. 42, pp. 347-357.

NOGUEIRA, R.M., COSTA, E.C., CARVALHO-FERNANDES, S.P. and SANTOS-SILVA, J., 2016. Insect galls from Serra Geral, Caetité, BA, Brazil. Biota Neotropica, vol. 16, no. 1, pp. e20150035. http://dx.doi.org/10.1590/1676-0611-BN-2015-0035.

PRICE, P.W., 2005. Adaptative radiation of gall-inducing insects. Basic and Applied Ecology, vol. 6, no. 5, pp. 413-421. http:// dx.doi.org/10.1016/j.baae.2005.07.002.

SANTANA, A.P. and ISAIAS, R.M.S., 2014. Galling insects are bioindicators of environmental quality in a Conservation Unit. Acta Botanica Brasílica, vol. 28, no. 4, pp. 594-608. http://dx.doi. org/10.1590/0102-33062014abb3510.

SANTOS, B.B., RIBEIRO, B.A., SILVA, T.M. and ARAÚJO, W.S., 2012. Galhas de insetos em uma área de cerrado sentido restrito na região semi-urbana de Caldas Novas (Goiás, Brasil). Revista Brasileira de Biociências, vol. 10, pp. 439-445.

SOUTHWOOD, T.R.E., 1960. The abundance of the Hawaiian trees and the number of their associated insect species. Proceedings of the Hawaiian Entomological Society, vol. 17, pp. 299-303. 
SOUTHWOOD, T.R.E., 1961. The number of species of insect associated with various trees. Journal of Animal Ecology, vol. 30, no. 1, pp. 1-8. http://dx.doi.org/10.2307/2109.

URSO-GUIMARÃES, M.V. and AMORIM, D.S., 2002. New Brazilian species of Asphondyliini (Diptera, Cecidomyiidae). Revista Brasileira de Entomologia, vol. 46, no. 4, pp. 561-570. http://dx.doi.org/10.1590/S0085-56262002000400011.

URSO-GUIMARÃES, M.V. and SCARELI-SANTOS, C., 2006. Galls and gall makers in plants from the Pé-de-Gigante Cerrado
Reserve, Santa Rita do Passa Quatro, SP, Brazil. Brazilian Journal of Biology $=$ Revista Brasileira de Biologia, vol. 66, no. 1B, pp. 357-369. PMid:16710528. http://dx.doi.org/10.1590/S151969842006000200018 .

URSO-GUIMARÃES, M.V., SCARELI-SANTOS, C. and BONIFÁCIO-SILVA, A.C., 2003. Occurrence and characterization of entomogen galls in plants from natural vegetation areas in Delfinópolis, MG, Brazil. Brazilian Journal of Biology $=$ Revista Brasileira de Biologia, vol. 63, no. 4, pp. 705-715. PMid:15029382. http://dx.doi.org/10.1590/S1519-69842003000400018. 